\title{
Ammonium removal efficiency of biochar-based heterotrophic nitrifying bacteria immobilization body in water solution
}

\author{
Chaoxu Wang ${ }^{1,2^{\dagger}}$, Jing Ren $^{1}$, Xin Qiao ${ }^{1,2}$, Mudassir Habib ${ }^{1}$ \\ ${ }^{1}$ College of Environmental Science and Engineering, Taiyuan University of Technology, 030600 Jinzhong, China \\ ${ }^{2}$ Innovation Center for Postgraduate Education in Municipal Engineering of Shanxi Province, 030600 Jinzhong, China
}

\begin{abstract}
In order to explore the performance of biochar-based microbial immobilization body in ammonium removal from water and potential mechanisms, a strain of heterotrophic nitrifying bacteria $(\mathrm{HNB})$ was isolated from activated sludge, and the biochemical and molecular biological identification of $\mathrm{HNB}$ was carried out. Moreover, $\mathrm{HNO}_{3^{-}}, \mathrm{Mg}^{2+}-, \mathrm{NaOH}-$, and $\mathrm{NaOH}+\mathrm{Mg}^{2+}$-modified rice husk-derived biochars were prepared. Then all the five kinds of biochars, including the original biochar, were used as carriers of $\mathrm{HNB}$ to remove $\mathrm{NH}_{4}{ }^{+}-\mathrm{N}$ from water. Results showed that $\mathrm{HNB}$ was classified as Pseudomonas, and the $72-\mathrm{h} \mathrm{NH}_{4}{ }^{+}-\mathrm{N}$ removal ratio of the free bacteria reached $80.24 \%$. Compared with biochar itself, biochar-based $\mathrm{HNB}$ immobilization body showed a much stronger ability to remove $\mathrm{NH}_{4}{ }^{+}-\mathrm{N}$, especially for $\mathrm{NaOH}-$ and $\mathrm{NaOH}+\mathrm{Mg}^{2+}-$ modified biochars. At the initial $\mathrm{NH}_{4}{ }^{+}-\mathrm{N}$ concentration of $100 \mathrm{mg} / \mathrm{L}$ and biochar addition dose of $10 \mathrm{~g} / \mathrm{L}, \mathrm{NH}_{4}{ }^{+}-\mathrm{N}$ removal ratio of $\mathrm{NaOH}-$ and $\mathrm{NaOH}+\mathrm{Mg}{ }^{2+}$-modified biochar-based HNB immobilization bodies reached $57.78 \%$ and $58.35 \%$ after $5 \mathrm{~h}$, and reached $88.66 \%$ and $90.93 \%$ after $48 \mathrm{~h}$ respectively, which were obviously higher than the original, $\mathrm{HNO}_{3}$ - and $\mathrm{Mg}^{2+}$-modified biochar-based $\mathrm{HNB}$ immobilization bodies. The phenomenon resulted from significantly higher bacteria adsorption ability of $\mathrm{NaOH}-$ and $\mathrm{NaOH}+\mathrm{Mg}^{2+}$-modified biochars, which reached 773.75 and $941.17 \mathrm{nmol} \mathrm{P} / \mathrm{g}$ biochar respectively.
\end{abstract}

Keywords: Ammonium removal, Biochar, Heterotrophic nitrifying bacteria, Immobilization body

\section{Introduction}

In recent years, the widespread application of chemical fertilizers has accelerated the accumulation of nitrogen in farmland, which in turn affects natural water bodies. Studies have shown that about $20 \%$ of nitrogen enters rivers and lakes through surface runoff, causing nitrogen pollution in surface waters [1]. Among them, $\mathrm{NH}_{4}{ }^{+}-\mathrm{N}$ is an important factor of the malodorous water bodies. Its degradation in water is a global environmental problem and has attracted more and more attention.

In order to address the serious problem of $\mathrm{NH}_{4}{ }^{+}-\mathrm{N}$ pollution, microbial immobilization technology (MIT) instead of the traditional suspension biotechnology emerges remarkably depending on its excellent performance in wastewater treatment [2]. MTT typically employs the physical, chemical, or biological methods to agglomerate free microbial cells into particles that are fixed or immobilized onto a particular material [3]. MIT can separate the treated water from microbial immobilization body readily, and enable immobilized microbes to be reused and remain active for a certain period of time [4]. Therefore, MT as a potential biological wastewater treatment technology showed bright prospect. Meanwhile, the selection of microbial immobilization carriers has become a research hotspot. Dong et al. [5] indicated that polyurethane immobilized nitrifying bacteria could achieve complete nitrification even at low ammonia concentrations, and they were more insensitive to temperature and $\mathrm{pH}$ than the suspended nitrifying bacteria. Yu et al. [6] studied the performance of heterotrophic nitrification-aerobic denitrifying bacteria immobilized on polyvinyl alcohol-alginate, $\mathrm{Fe}_{3} \mathrm{O}_{4}$ nanoparticles, and bacterial cellulose, respectively. Their results showed that the bacterial cellulose-based bacteria immobilization body achieved $77.22 \%$ sewage total nitrogen removal. However, the above-mentioned bacteria immobilization carriers generally face problems such as low mechanical strength and high price.

Biochar (BC) is produced by pyrolysis of the organic agricultural waste under the condition of limited oxygen, which is stable, diffi-
This is an Open Access article distributed under the terms of the Creative Commons Attribution Non-Commercial License (http://creativecommons.org/licenses/by-nc/3.0/) which permits unrestricted non-commercial use, distribution, and reproduction in any medium, provided the original work is properly cited.

Copyright (C) 2021 Korean Society of Environmental Engineers
Received November 07, 2019 Accepted March 08, 2020

${ }^{\dagger}$ Corresponding author

Email: cxwang127@126.com

Tel: +86-0351-3176586 Fax: +86-0351-3176586

ORCID: 0000-0003-1031-1112 
cult to dissolve in water, and with high carbon content $[7,8]$. In recent years, scientists have found that $\mathrm{BC}$ has the characteristics of cost-effectiveness, various sources of feedstock and particular physical and chemical properties, such as large specific surface area and high porosity, which provide a favorable habitat for bacteria and enhance the pollutant removal efficiency and is very suitable as a microbial immobilization carrier [9, 10]. Many literatures have shown that BC is an ideal microbial immobilization carrier. Zhang et al. [11] demonstrated that the immobilization of Corynebacterium variabile HRJ4 with wood chips BC showed higher degradation of total petroleum hydrocarbons up to 78.9\% after 7-d incubation as compared to the free bacteria. Abu Talha et al. [12] found that the degradation of Congo red dye of coconut shell BC-based immobilization body was significantly higher than that of free cells. The result was mainly due to the large specific surface area of coconut shell BC, which dramatically increased the contact area between dye and microbes and the active site on the BC, which can help the microbes to capture the contaminant in bulk solution. Moreover, previous studies showed that acid or alkali modifications can enhance $\mathrm{NH}_{4}{ }^{+}-\mathrm{N}$ adsorption capacity of BCs [13-15]. The increased active sites on modified BCs could facilitate the catchment of $\mathrm{NH}_{4}{ }^{+} \mathrm{N}$ from bulk solution which was further degraded by the bacteria immobilized on the surface of BC and thus renewing the pores for subsequent adsorption. However, there is little study about modified biochar-based bacteria immobilization bodies on $\mathrm{NH}_{4}{ }^{+}-\mathrm{N}$ removal from water, and the underlying mechanism for different performances of BC-based bacteria immobilization bodies, especially for the carriers of acid, alkali or metal ions modified BCs, to remove $\mathrm{NH}_{4}{ }^{+}-\mathrm{N}$ in water is not very clear.

Therefore, the study prepared and characterized the $\mathrm{HNO}_{3}^{-}$, $\mathrm{Mg}^{2+}-, \mathrm{NaOH}-$, and $\mathrm{NaOH}+\mathrm{Mg}^{2+}$-modified rice husk-derived $\mathrm{BCs}$ firstly. Then the immobilized bodies of the HNB screened from a wastewater treatment plant, based on all the five kinds of BCs (including the original one), were prepared by using the adsorption method, and $\mathrm{NH}_{4}{ }^{+}-\mathrm{N}$ removal efficiency of the BC-based HNB immobilized bodies and the potential mechanism were explored. The study will serve as a theoretical basis for the large-scale wastewater treatment engineering application of BC-based microbial immobilization.

\section{Material and Methods}

\subsection{Enrichment and Isolation of Heterotrophic Nitrifying Bacteria}

HNB were enriched from the activated sludge collected from the oxidation ditch of Xi'an Wastewater Treatment Plant No. 3. HNB enrichment experiment was operated by adding $20 \mathrm{~mL}$ supernatant of the active sludge to $180 \mathrm{~mL}$ heterotrophic nitrification liquid medium (HNLM) (g/L, sodium citrate 4.32, $\left(\mathrm{NH}_{4}\right)_{2} \mathrm{SO}_{4} 0.548, \mathrm{KH}_{2} \mathrm{PO}_{4}$ 1.50, $\mathrm{Na}_{2} \mathrm{HPO}_{4} \cdot 12 \mathrm{H}_{2} \mathrm{O} 10.50, \mathrm{MgSO}_{4} \cdot 7 \mathrm{H}_{2} \mathrm{O} 0.20$; microelement solution $2 \mathrm{~mL} / \mathrm{L}$, pH 7.0 7.5; microelement solution $\left(\mathrm{g} / \mathrm{L}, \mathrm{ZnSO}_{4} 2.2\right.$, $\mathrm{FeSO}_{4} \cdot 7 \mathrm{H}_{2} \mathrm{O}$ 3.0, $\mathrm{CaCl}_{2} 5.5, \mathrm{MnCl}_{2} \cdot 4 \mathrm{H}_{2} \mathrm{O}$ 5.0, $\mathrm{CuSO}_{4} \cdot 5 \mathrm{H}_{2} \mathrm{O}$ 1.6, $\mathrm{CoCl}_{2} \cdot 6 \mathrm{H}_{2} \mathrm{O}$ 1.6, $\left(\mathrm{NH}_{4}\right)_{6} \mathrm{Mo}_{7} \mathrm{O}_{2} \cdot 4 \mathrm{H}_{2} \mathrm{O}$ 1.1); $\left.\mathrm{pH} 7.0 \sim 7.5\right)$, and then the mixture was incubated on the shaker $\left(30^{\circ} \mathrm{C}, 170 \mathrm{r} / \mathrm{min}\right)$ for $3 \mathrm{~d}$. After clarification, the supernatant was collected and inoculated into HNLM at the ratio of $1 \%(\mathrm{v} / \mathrm{v})$ and incubated for another
$3 \mathrm{~d}\left(30^{\circ} \mathrm{C}, 170 \mathrm{r} / \mathrm{min}\right)$, and this step was repeated for three times with the same manner. HNB enrichment experiment was manipulated with 6 replicates.

Pure HNB strains were gained through the plate smearing and repeated plate streaking method. The enriched HNB suspension was diluted with sterilized water for $10^{-7} \sim 10^{-12}$ times, and then $1 \mathrm{~mL}$ inoculum was spread evenly on the heterotrophic nitrification solid medium (HNSM) (the same nutrient content as HNLM but with agar (20 g/L) addition). In all, 36 Petri dishes were gained and transferred to a biochemical incubator $\left(30^{\circ} \mathrm{C}\right)$ for about $4 \mathrm{~d}$. Then the single colony (usually occurred at the $10^{-11}$ and $10^{-12}$ dilution gradients) was selected for repeated plate streaking separation.

To purify the isolated HNB, the selected single colony was streaked on HNSM using a sterilized inoculating loop and incubated at $30^{\circ} \mathrm{C}$ for about $4 \mathrm{~d}$. The streaking manipulation was carried out about 3 times based on the previous streaked plate until all the colonies on the surface of the culture-medium were clear and without mixed and associated bacteria. In all, three pure HNB strains (designated as Strain-II, S2-1, and S2-2) were isolated, and they were saved on the agar slant culture-medium with $\mathrm{HNB}$ specificity at $4^{\circ} \mathrm{C}$.

\subsection{Identification of the Isolated HNB}

\subsubsection{Biochemical identification}

To explore $\mathrm{NH}_{4}{ }^{+}-\mathrm{N}$ degradation dynamics of the three isolated HNB strains, they were inoculated into $200 \mathrm{~mL} \mathrm{HNLM} \mathrm{(initial}$ $\mathrm{NH}_{4}{ }^{+}-\mathrm{N} 116.18 \mathrm{mg} / \mathrm{L}$ ) and incubated on a shaker (170 r/min) at $30^{\circ} \mathrm{C}$ for $72 \mathrm{~h}$, respectively. The thoroughly mixed suspension (4 $\mathrm{mL}$ ) was withdrawn from the conical flask at an interval of $8 \mathrm{~h}$ during the incubation period. The concentration of $\mathrm{NH}_{4}{ }^{+}-\mathrm{N}, \mathrm{NO}_{3}{ }^{-}-\mathrm{N}$, $\mathrm{NO}_{2}^{-}-\mathrm{N}$, and total nitrogen (TN) was determined after the suspension was filtered through a $0.22 \mu \mathrm{m}$ MF-Millipore Membrane. $\mathrm{NH}_{4}{ }^{+}-\mathrm{N}$, $\mathrm{NO}_{3}^{-}-\mathrm{N}$, and $\mathrm{NO}_{2}^{-}-\mathrm{N}$ concentrations were determined by a colorimetric method using UV/Vis spectrophotometer (752, Jinghua Instruments, Shanghai) at the wavelength of $420,220 / 275$, and $540 \mathrm{~nm}$, respectively. TN was determined by the alkaline potassium persulfate oxidation method [16]. Considering the potential function of heterotrophic nitrification and aerobic denitrification of Strain-II, just Strain-II was used for further study. The $\mathrm{NH}_{4}{ }^{+}-\mathrm{N}$ degradation performance of the other two strains was shown in Fig. S1 of the Supplementary Materials (SM).

\subsubsection{Molecular biological identification}

Bacterium genomic DNA was extracted by using the Ezup column-type bacterium genomic DNA extraction Kit (Sango Biotech, Shanghai). Genomic DNA was subject to PCR amplification of $16 \mathrm{~S}$ rDNA gene with the universal primers 27F (AGT TTG ATC MTG GCT CAG) and 1492R (GGT TAC CTT GTT ACG ACT T) [17]. PCR product was purified before sequencing using SanPrep column-type DNA gel extraction Kit (Sango Biotech, Shanghai) and then sequenced by automated DNA sequencer 3100 DNA Analyzer from Applied Biosystems using BigDye Terminator v1.1 cycle sequencing Kit by $1 / 2$ reaction system (Applied Biosystems, USA).

Further, the sequence obtained was aligned manually with published sequences in the NCBI database using CLUSTALW multiple sequence alignment program. Phylogenetic analyses were conducted using MEGA version 4.0 and the neighbor-joining method was used to calculate the distances and to construct a phylogenetic 
tree. The 16S rDNA gene sequence of Strain-II has been submitted to the GenBank database under accession number MK621209.

\subsection{Immobilization of the Isolated HNB by Biochar}

\subsubsection{Biochar preparation}

The biochar (BC) used for microbial immobilization was purchased from the company of Kansai (Japan), which was produced from rice husk at the carbonization temperature of $500^{\circ} \mathrm{C}$. Besides the original rice husk-derived $\mathrm{BC}$, there were four kinds of modified rice husk-derived $\mathrm{BC}$, i.e. $\mathrm{HNO}_{3^{-}}, \mathrm{Mg}^{2+}-, \mathrm{NaOH}-$, and $\mathrm{NaOH}+\mathrm{Mg}^{2+}$-modified BCs, were also used as carriers for microbial immobilization. The detailed information about the method of making modified $\mathrm{BC}$ was shown in SM. $\mathrm{pH}$ and electrical conductivity (EC) of the original and modified BCs were determined with a $\mathrm{BC}$ to water ratio of 1:15 (g:mL) using a $\mathrm{pH}$ meter (Mettler Toledo Delta 320) and an EC meter (DDS-307A, Shanghai Instrument Science), respectively. The surface charge distribution of BC was characterized by $\mathrm{pH}_{\mathrm{pzc}}$, which was determined by the same method as Čerović et al. [18]. The specific surface area, total pore volume, and mean pore size of $\mathrm{BC}$ were determined by a surface area analyzer (Quadrasorb SI). BC surface oxygen-containing functional groups were determined by the Boehm titration method [19].

\subsubsection{Biochar-based HNB immobilization body preparation}

The BC-based HNB immobilization body was prepared by adsorption method using original and modified BCs, respectively. The saved Strain-II was inoculated into $200 \mathrm{~mL} \mathrm{LB}$ liquid medium (g/L: tryptone 10.0, yeast extract 5.0, $\mathrm{NaCl} 10.0, \mathrm{pH} 7.0 \sim 7.5$ ), and incubated on a shaker $\left(30^{\circ} \mathrm{C}, 170 \mathrm{r} / \mathrm{min}\right)$ for about $24 \mathrm{~h}$ until the $\mathrm{OD}_{600}$ of the suspension reached $1.0\left(\mathrm{OD}_{600}\right.$, the absorbance at 600 $\mathrm{nm}$ ). After centrifugated at 12,000 r/min for $3 \mathrm{~min}$, the bacteria were washed by resuspension in sterilized water and centrifuging for another 2 times. Finally, the bacteria were resuspended in 200 $\mathrm{mL}$ sterilized water, which was called the seed solution. The prepared BC (2.0 g) was put into a sterilized conical flask containing $200 \mathrm{~mL}$ seed solution, and incubated on a shaker $\left(30^{\circ} \mathrm{C}, 150 \mathrm{r} / \mathrm{min}\right)$ for $24 \mathrm{~h}$ to facilitate the bacteria immobilizing onto the surface of BC. After that, BC possessing immobilized bacteria was filtered and rinsed with sterilized water, which was named as BC-based HNB immobilization body.

\subsection{Performance of Biochar-based HNB Immobilization Body and Biochar on $\mathrm{NH}_{4}^{+}-\mathrm{N}$ Removal}

To explore $\mathrm{NH}_{4}{ }^{+}-\mathrm{N}$ removal ability of the original and modified BC-based HNB immobilization bodies, $2.0 \mathrm{~g}$ BC-based HNB immobilization body was added in $300 \mathrm{~mL}$ conical flask containing 200 $\mathrm{mL} \mathrm{HNLM}$ (the initial concentration of $\mathrm{NH}_{4}{ }^{+}-\mathrm{N}$ in $\mathrm{HNLM}$ was adjusted at 100, 200 and $300 \mathrm{mg} / \mathrm{L}$, respectively). Then the conical flasks were put on a shaker $\left(30^{\circ} \mathrm{C}, 170 \mathrm{r} / \mathrm{min}\right)$ for $48 \mathrm{~h}$. The thoroughly mixed suspension of $1 \mathrm{~mL}$ was sampled from the conical flask at $1 / 6,0.5,1,2,5,8,12,18,24,31,39$, and $48 \mathrm{~h}$ during the incubation. The concentration of $\mathrm{NH}_{4}{ }^{+}-\mathrm{N}$ was determined after the suspension was filtered through a $0.22 \mu \mathrm{m}$ MF-Millipore Membrane. $\mathrm{NH}_{4}{ }^{+}-\mathrm{N}$ concentration was determined by the colorimetric method as mentioned before.

The highest $\mathrm{NH}_{4}{ }^{+}-\mathrm{N}$ removal efficiency that $\mathrm{NaOH}-$ and
$\mathrm{NaOH}+\mathrm{Mg}^{2+}$-modified BC-based $\mathrm{HNB}$ immobilization bodies showed inspired us to explore how about $\mathrm{NaOH}^{-}$and $\mathrm{NaOH}+\mathrm{Mg}^{2+}$-modified $\mathrm{BC}$ adsorption in $\mathrm{NH}_{4}{ }^{+}-\mathrm{N}$ removal. Then the $\mathrm{NH}_{4}{ }^{+}-\mathrm{N}$ adsorption kinetics experiment of the original and modified BCs was carried out. The original or modified BC $(2.0$ g) was put into a conical flask which contained $200 \mathrm{~mL}\left(\mathrm{NH}_{4}\right)_{2} \mathrm{SO}_{4}$ solution with the initial $\mathrm{NH}_{4}{ }^{+}-\mathrm{N}$ concentrations of 100, 200 and $300 \mathrm{mg} / \mathrm{L}$, respectively. In all, there were 15 treatments (5 adsorbents $\times 3$ initial concentrations), and each treatment was carried out with three replicates. Then the conical flasks were incubated on a shaker $\left(30^{\circ} \mathrm{C}, 170 \mathrm{r} / \mathrm{min}\right)$ for $5 \mathrm{~h}$. According to our previous study [20], the adsorption of $\mathrm{NH}_{4}{ }^{+}-\mathrm{N}$ by BC would reach equilibrium for about $5 \mathrm{~h}$. Then $10 \mathrm{~mL}$ suspension was sampled and filtrated through a $0.45 \mu \mathrm{m}$ MF-Millipore Membrane, and the concentration of $\mathrm{NH}_{4}{ }^{+}-\mathrm{N}$ was determined by the same colorimetric method.

\subsection{Determination of Microbial Amount Adsorbed by Original and Modified Biochars}

To explore the difference of microbial adsorption ability of the original and modified BCs, microbial amount adsorbed by BCs was determined. The number of living microbes could be indicated by the phospholipid content of cell membrane. The phospholipid analytical technique was used to evaluate the number of microbes attached to the surfaces of BC [21]. The HNB immobilization body based on $0.1 \mathrm{~g} \mathrm{BC}$ was added to a sterilized conical flask containing phospholipid extract solution (10 mL chloroform, $20 \mathrm{~mL}$ methanol, and $8 \mathrm{~mL}$ water, with the volume ratio of 1:2:0.8). After shaking for $10 \mathrm{~min}$ vigorously and standing still for $12 \mathrm{~h}, 10 \mathrm{~mL}$ chloroform and $10 \mathrm{~mL}$ water were compensated making the chloroform: methanol: water volume ratio being right on 1:1:0.9, and then the suspension was standing still for $12 \mathrm{~h}$ again. The chloroform containing the phospholipid in the deep layer of the mixture was transferred to a digestion tube, and the chloroform was evaporated in a water bath at $70^{\circ} \mathrm{C}$. After digested by $4 \mathrm{~mL}$ potassium persulfate $(5 \%, 5 \mathrm{~g} / 100 \mathrm{~mL})$ at $120^{\circ} \mathrm{C}$ for $30 \mathrm{~min}$, the extracted phospholipid (nmol P/g BC) was determined by a colorimetric method at the wavelength of $700 \mathrm{~nm}$.

\subsection{Data Analysis}

The variance between any triplicate measurements in this study was smaller than $5 \%$, and the average value \pm standard deviation was reported ( $\mathrm{n}=3$ ). Variance analysis (one-way ANOVA) was examined by the protected LSD multiple range test $(p<0.05)$ using the software Statistica 6.0. The graphing was performed using OriginPro 8.0 software.

\section{Results and Discussion}

\subsection{Biochemical and Molecular Identification of HNB}

The isolated single colony was inoculated into the heterotrophic nitrification liquid medium (HNLM), and the nitrifying ability of Strain-II was identified by measuring the dynamic changes of $\mathrm{NH}_{4}{ }^{+}-\mathrm{N}, \mathrm{NO}_{3}^{-}-\mathrm{N}, \mathrm{NO}_{2}^{-}-\mathrm{N}$, and $\mathrm{TN}$ concentration in the medium. The results indicated that $\mathrm{NH}_{4}{ }^{+}-\mathrm{N}$ decreased from 116.18 to 49.75 $\mathrm{mg} / \mathrm{L}$ during $0 \sim 24 \mathrm{~h}$, and the average degradation rate was 2.77 $\mathrm{mg} /(\mathrm{L} \cdot \mathrm{h})$. However, a slow $\mathrm{NH}_{4}{ }^{+}-\mathrm{N}$ degradation rate $(0.56 \mathrm{mg} /(\mathrm{L} \cdot \mathrm{h}))$ 
was observed during $24 \sim 72 \mathrm{~h}$, and $\mathrm{NH}_{4}{ }^{+}-\mathrm{N}$ reduced to $22.96 \mathrm{mg} / \mathrm{L}$ at the end of incubation. TN decreased from 116.18 to $91.37 \mathrm{mg} / \mathrm{L}$ during the whole incubation, and the average degradation rate was $0.35 \mathrm{mg} /(\mathrm{L} \cdot \mathrm{h}) . \mathrm{NO}_{3}^{-}-\mathrm{N}$ and $\mathrm{NO}_{2}^{-}-\mathrm{N}$ were always stayed at the

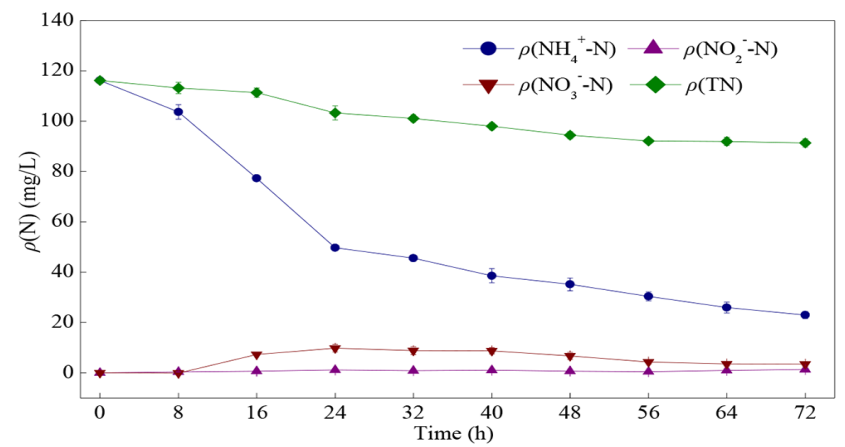

Fig. 1. The dynamics of inorganic nitrogen and total nitrogen concentrations in the enrichment liquid medium with HNB specificity. relatively low level, with the maximum value of 9.80 and 1.37 $\mathrm{mg} / \mathrm{L}$, respectively (Fig. 1). In all, the isolated Strain-II has the heterotrophic nitrification ability.

The neighbor-joining phylogenetic tree of $16 \mathrm{~S}$ rDNA gene of the isolated Strain-II was shown in Fig. 2. The homology comparison with the nucleic acid sequences in the GenBank showed that the isolated Strain-II had a closer evolutionary distance (similarity 99\%) with Pseudomonas sp. strain SMCC B0310 (AF500620). So, the isolated strain was named as Pseudomonas sp. Strain-II (MK621209). The genus Pseudomonas has been recorded frequently possessing the ability of heterotrophic nitrification [22, 23].

\subsection{Effects of Different Modification Methods on Biochar Physicochemical Properties}

The physicochemical properties of the original and modified rice husk-derived biochars (BCs) were shown in Table 1. BC's inherent characteristics decided its suitability as a microbial immobilization carrier. The $\mathrm{pH}$ of $\mathrm{HNO}_{3}$ - and $\mathrm{Mg}^{2+}$-modified $\mathrm{BCs}(4.30 \pm 0.30$

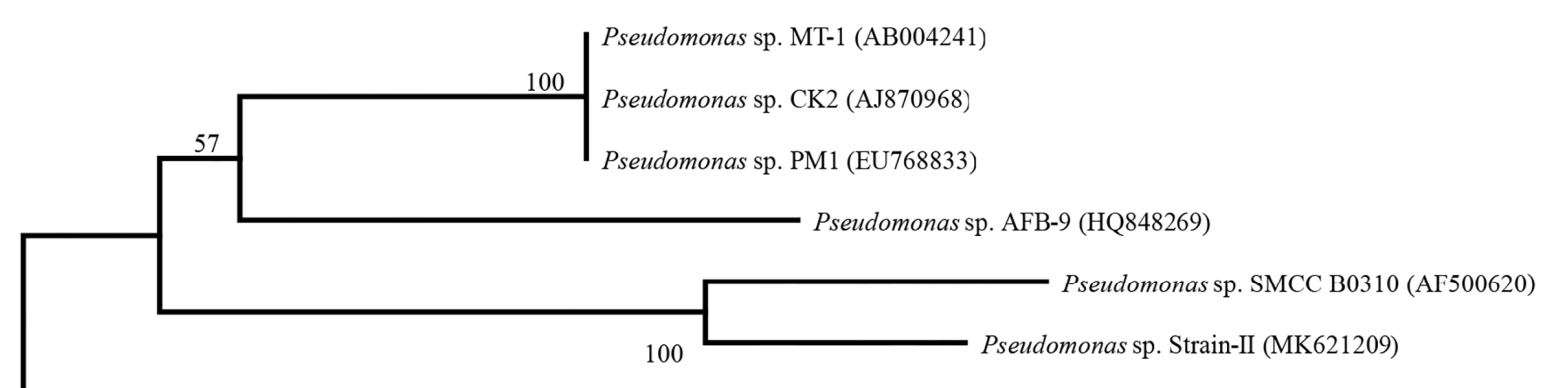

Pseudomonas sp. Fa2 (AY747590

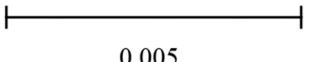

0.005

Fig. 2. Neighbor-joining phylogenetic tree of $16 \mathrm{~S}$ rDNA gene of the heterotrophic nitrifying bacterium Pseudomonas sp. Strain-II isolated from the active sludge (bootstrap values (100 iterations) greater than $50 \%$ are shown).

Table 1. Physicochemical Properties of Original and Modified Rice Husk-derived Biochars (BCs)

\begin{tabular}{|c|c|c|c|c|c|}
\hline & Original BC & $\begin{array}{l}\mathrm{HNO}_{3^{-}} \\
\text {modified BC }\end{array}$ & $\begin{array}{l}\mathrm{Mg}^{2+}- \\
\text { modified BC }\end{array}$ & $\begin{array}{l}\text { NaOH- } \\
\text { modified BC }\end{array}$ & $\begin{array}{l}\mathrm{NaOH}+\mathrm{Mg}^{2+}- \\
\text { modified } \mathrm{BC}\end{array}$ \\
\hline $\mathrm{pH}$ (BC/water ratio, $1 \mathrm{~g}: 15 \mathrm{~mL})$ & $8.78 \pm 0.27^{\mathrm{a}}$ & $4.30 \pm 0.30^{\mathrm{b}}$ & $7.78 \pm 0.62^{\mathrm{C}}$ & $9.33 \pm 0.37^{\mathrm{a}}$ & $10.20 \pm 0.30^{\mathrm{d}}$ \\
\hline $\mathrm{EC}(\mathrm{mS} / \mathrm{m})$ & $25.00 \pm 1.67^{\mathrm{a}}$ & $45.13 \pm 2.21^{\mathrm{b}}$ & $17.97 \pm 1.47^{\mathrm{C}}$ & $23.27 \pm 2.46^{\mathrm{ad}}$ & $21.13 \pm 1.55^{\mathrm{cd}}$ \\
\hline $\mathrm{pH}_{\mathrm{pzc}}$ & $5.77 \pm 0.15^{\mathrm{a}}$ & $2.67 \pm 0.31^{\mathrm{b}}$ & $6.13 \pm 0.65^{\mathrm{a}}$ & $8.87 \pm 0.57^{\mathrm{C}}$ & $8.13 \pm 0.76^{\mathrm{C}}$ \\
\hline Carboxyl (mmol/g) & $0.288 \pm 0.040^{\mathrm{a}}$ & $0.954 \pm 0.185^{\mathrm{b}}$ & $0.279 \pm 0.138^{\mathrm{a}}$ & $0.018 \pm 0.000^{\mathrm{C}}$ & $0.047 \pm 0.000^{\mathrm{C}}$ \\
\hline Carbonyl (mmol/g) & $0.536 \pm 0.157^{\mathrm{a}}$ & $0.905 \pm 0.115^{\mathrm{b}}$ & $0.536 \pm 0.157^{\mathrm{a}}$ & $0.770 \pm 0.157^{\mathrm{ab}}$ & $0.701 \pm 0.136^{\mathrm{ab}}$ \\
\hline Phenolic hydroxyl (mmol/g) & $0.171 \pm 0.110^{\mathrm{a}}$ & $0.224 \pm 0.052^{\mathrm{a}}$ & $0.225 \pm 0.086^{\mathrm{a}}$ & $0.022 \pm 0.045^{\mathrm{b}}$ & $0.082 \pm 0.096^{\mathrm{ab}}$ \\
\hline $\begin{array}{l}\text { Total acidic oxygen-containing } \\
\text { functional group }(\mathrm{mmol} / \mathrm{g})\end{array}$ & $0.996 \pm 0.245^{\mathrm{a}}$ & $2.084 \pm 0.220^{\mathrm{b}}$ & $1.039 \pm 0.210^{\mathrm{a}}$ & $0.797 \pm 0.160^{\mathrm{a}}$ & $0.789 \pm 0.097^{\mathrm{a}}$ \\
\hline $\begin{array}{l}\text { Total alkaline oxygen-containing } \\
\text { functional group (mmol/g) }\end{array}$ & $0.787 \pm 0.175^{\mathrm{ab}}$ & $0.041 \pm 0.000^{\mathrm{c}}$ & $0.639 \pm 0.191^{\mathrm{a}}$ & $1.317 \pm 0.142^{\mathrm{d}}$ & $1.015 \pm 0.126^{\mathrm{b}}$ \\
\hline Specific surface area $\left(\mathrm{m}^{2} / \mathrm{g}\right)$ & 53.77 & 85.54 & 88.80 & 160.92 & 191.28 \\
\hline Total pore volume $\left(\mathrm{cm}^{3} / \mathrm{g}\right)$ & 0.0435 & 0.0649 & 0.0648 & 0.1238 & 0.1392 \\
\hline Mean pore size (nm) & 3.24 & 3.03 & 2.92 & 3.08 & 2.91 \\
\hline
\end{tabular}

Note: data in the same row followed by the same letter are not significantly different at $\mathrm{p}<0.05$ level of probability; mean \pm SD $(n=3)$. The data of specific surface area, total pore volume, and mean pore size refer to the mesopore $(2 \sim 50 \mathrm{~nm})$ of $\mathrm{BC}$. 
and $7.78 \pm 0.62$, respectively) was significantly lower than original $\mathrm{BC}(8.78 \pm 0.27)$, while the $\mathrm{pH}$ of $\mathrm{NaOH}+\mathrm{Mg}^{2+}$-modified $\mathrm{BC}(10.20$ \pm 0.30 ) was significantly higher than original $\mathrm{BC}(\mathrm{p}<0.05)$. The $\mathrm{pH}_{\mathrm{pzc}}$ of $\mathrm{HNO}_{3}$-modified $\mathrm{BC}(2.67 \pm 0.31)$ was significantly lower than original $\mathrm{BC}(5.77 \pm 0.15)$, while the $\mathrm{pH}_{\mathrm{pzc}}$ of $\mathrm{NaOH}$ - and $\mathrm{NaOH}+\mathrm{Mg}^{2+}$-modified $\mathrm{BCs}(8.87 \pm 0.57$ and $8.13 \pm 0.76$, respectively) was significantly higher than original BC $(\mathrm{p}<0.05)$. Though the total acidic oxygen-containing functional group amount of $\mathrm{NaOH}-$ and $\mathrm{NaOH}+\mathrm{Mg}^{2+}$-modified $\mathrm{BCs}(0.797 \pm 0.160$ and 0.789 $\pm 0.097 \mathrm{mmol} / \mathrm{g}$, respectively) were lower than original BC $(0.996$ $\pm 0.245 \mathrm{mmol} / \mathrm{g}$ ), the difference was not significant $(\mathrm{p}<0.05)$. The total alkaline oxygen-containing functional group amount of $\mathrm{NaOH}$-modified BC $(1.317 \pm 0.142 \mathrm{mmol} / \mathrm{g})$ was significantly higher than the original $\mathrm{BC}(0.787 \pm 0.175 \mathrm{mmol} / \mathrm{g})$. Moreover, the total alkaline oxygen-containing functional group amount of $\mathrm{NaOH}+\mathrm{Mg}^{2+}$-modified BC $(1.015 \pm 0.126 \mathrm{mmol} / \mathrm{g})$ was also higher than the original $\mathrm{BC}$, but the difference was not significant ( $\mathrm{p}$ $<0.05$ ). Compared with original BC, all the four kinds of modification methods increased the specific surface area of the BCs with different extent. The specific surface area of the $\mathrm{HNO}_{3}-, \mathrm{Mg}^{2+}$, $\mathrm{NaOH}$-, and $\mathrm{NaOH}+\mathrm{Mg}^{2+}$-modified BCs was 1.59, 1.65, 2.99, and 3.56 times higher than the original $\mathrm{BC}$, respectively.

$\mathrm{HNO}_{3}$ modification significantly $(\mathrm{p}<0.05$ ) increased BC carboxyl, carbonyl, and total acidic oxygen-containing functional group amounts with the greatest extent among all the four modification methods. The acidic oxygen-containing functional group of $\mathrm{HNO}_{3}$-modified $\mathrm{BC}$ released $\mathrm{H}^{+}$, making the lowest value of $\mathrm{pH}_{\mathrm{pzc}}$ [24]. Moreover, the corrosion effect of $\mathrm{HNO}_{3}$ on $\mathrm{BC}$ pore walls led to increased specific surface area and total pore volume [25]. However, the acidic oxygen-containing functional group has a definite antibacterial effect, and the $\mathrm{H}^{+}$released into the solution may cause bacteria activity decrease [26].

$\mathrm{NaOH}$ and $\mathrm{NaOH}+\mathrm{Mg}^{2+}$ modification significantly increased the $\mathrm{pH}$ and $\mathrm{pH}_{\mathrm{pzc}}$ of $\mathrm{BC}$, which resulted from the neutralization of biochar acidic oxygen-containing functional group with alkali. Shim et al. [25] showed that $\mathrm{NaOH}$ modification decreased the carboxyl amount of activated carbon, rendering increased $\mathrm{pH}_{\mathrm{pzc}}$, and inferred that the amount of acidic oxygen-containing functional group was the major factor controlling $\mathrm{pH}_{\mathrm{pzc}}$. A similar result was further explored by Zhou et al. [24]. The specific surface area of $\mathrm{BC}$ was linked to its pore structure closely. $\mathrm{NaOH}$ and $\mathrm{NaOH}+\mathrm{Mg}^{2+}$ modification made the biochar specific surface area increase by 1.99 and 2.56 times compared with the original BC, respectively, which may result from the etching effect of $\mathrm{NaOH}$ on $\mathrm{BC}$ pores [27].

\subsection{Performance of Biochar-based HNB Immobilization Body on $\mathrm{NH}_{4}^{+}-\mathrm{N}$ Removal}

$\mathrm{NH}_{4}{ }^{+}-\mathrm{N}$ removal dynamics of the original and modified BC-based HNB immobilization bodies was explored within $48 \mathrm{~h}$ under the initial $\mathrm{NH}_{4}{ }^{+}-\mathrm{N}$ concentration of 100, 200, and $300 \mathrm{mg} / \mathrm{L}$. The results showed that $\mathrm{NH}_{4}{ }^{+}-\mathrm{N}$ removal ratio of the original, $\mathrm{HNO}_{3}-, \mathrm{Mg}^{2+}$, $\mathrm{NaOH}$-, and $\mathrm{NaOH}+\mathrm{Mg}^{2+}$-modified BC-based $\mathrm{HNB}$ immobilization bodies during $48 \mathrm{~h}$ was $42.20 \%, 45.73 \%, 55.58 \%, 88.66 \%$, and 90.93\%, respectively at the initial $\mathrm{NH}_{4}{ }^{+}-\mathrm{N}$ concentration of 100 $\mathrm{mg} / \mathrm{L}$. Moreover, at the initial $\mathrm{NH}_{4}{ }^{+}-\mathrm{N}$ concentration of $200 \mathrm{mg} / \mathrm{L}$,
$\mathrm{NH}_{4}{ }^{+}-\mathrm{N}$ removal ratio was $33.60 \%, 45.59 \%, 51.40 \%, 76.40 \%$, and $78.67 \%$, respectively, and at the initial $\mathrm{NH}_{4}{ }^{+}-\mathrm{N}$ concentration of $300 \mathrm{mg} / \mathrm{L}, \mathrm{NH}_{4}{ }^{+}-\mathrm{N}$ removal ratio was $24.92 \%, 25.77 \%, 28.80 \%$, $45.04 \%$, and $47.06 \%$, respectively. $\mathrm{NaOH}+\mathrm{Mg}^{2+}$-modified BC-based HNB immobilization bodies possessed the strongest ability to remove $\mathrm{NH}_{4}{ }^{+}-\mathrm{N}$ from water, while the original BC-based $\mathrm{HNB}$ immobilization bodies possessed the weakest ability to remove $\mathrm{NH}_{4}{ }^{+}-\mathrm{N}$ either with the initial $\mathrm{NH}_{4}{ }^{+}-\mathrm{N}$ concentration of 100,200 or $300 \mathrm{mg} / \mathrm{L}$. On the other hand, as the initial $\mathrm{NH}_{4}{ }^{+} \mathrm{N}$ concentration increased from 100 to $300 \mathrm{mg} / \mathrm{L} \mathrm{NH}_{4}{ }^{+}-\mathrm{N}$ removal ratio of the original and modified BC-based HNB immobilization bodies was decreased (Fig. 3(a), (c), (e)).

$\mathrm{NH}_{4}{ }^{+}-\mathrm{N}$ removal rate of the original, $\mathrm{HNO}_{3}{ }^{-}, \mathrm{Mg}^{2+}-, \mathrm{NaOH}-$, and $\mathrm{NaOH}+\mathrm{Mg}^{2+}$-modified BC-based $\mathrm{HNB}$ immobilization bodies reached the peak at about $5 \mathrm{~h}$ after incubation either with the initial $\mathrm{NH}_{4}{ }^{+}-\mathrm{N}$ concentration of 100, 200 or $300 \mathrm{mg} / \mathrm{L}$. The high-efficiency period of $\mathrm{NH}_{4}{ }^{+}-\mathrm{N}$ removal of the immobilization bodies occurred from 1 to $8 \mathrm{~h}$, and the $\mathrm{NH}_{4}{ }^{+}-\mathrm{N}$ removal rate tended to be zero at $24 \mathrm{~h}$. Moreover, among all the five kinds of BCs, $\mathrm{NaOH}$ and $\mathrm{NaOH}+\mathrm{Mg}^{2+}$-modified BC-based $\mathrm{HNB}$ immobilization bodies showed the maximum $\mathrm{NH}_{4}{ }^{+}-\mathrm{N}$ removal rate $(100 \mathrm{mg} / \mathrm{L}$ : 15.64 and $15.20 \mathrm{mg} /(\mathrm{L} \cdot \mathrm{h}) ; 200 \mathrm{mg} / \mathrm{L}: 25.73$ and $26.63 \mathrm{mg} /(\mathrm{L} \cdot \mathrm{h}) ; 300 \mathrm{mg} / \mathrm{L}$ : 17.82 and $17.43 \mathrm{mg} /(\mathrm{L} \cdot \mathrm{h})$ ) (Fig. 3(b), (d), (f)).

$\mathrm{NH}_{4}{ }^{+} \mathrm{N}$ removal rates of bacteria immobilization body in water solution varied considerably under various initial $\mathrm{NH}_{4}{ }^{+}-\mathrm{N}$ concentration, immobilization method, and microorganism species. Yu et al. [28] indicated the complex of modified walnut shell biochar and Pseudomonas stutzeri strain XL-2 showed the maximum average $\mathrm{NH}_{4}{ }^{+}-\mathrm{N}$ removal rate of $4.40 \mathrm{mg} /(\mathrm{L} \cdot \mathrm{h})$, and approximately $96.34 \%-98.73 \%$ of $\mathrm{NH}_{4}{ }^{+}-\mathrm{N}$ was removed in a sequencing batch reactor inoculating with the complex of strain XL-2 and biochar. Compared with our study, the relatively low $\mathrm{NH}_{4}{ }^{+}-\mathrm{N}$ removal rate may result from the low initial $\mathrm{NH}_{4}{ }^{+}-\mathrm{N}$ input. Khan et al. [29] observed stable nitritation over 300 days with $\mathrm{NH}_{4}{ }^{+}-\mathrm{N}$ loading rate of $45.83 \mathrm{mg} /(\mathrm{L} \cdot \mathrm{h})$ in a sequencing batch reactor filled with cell-immobilized polyethylene glycol pellets and found $\mathrm{NH}_{4}{ }^{+}-\mathrm{N}$ removal rates were more than $43.54 \mathrm{mg} /(\mathrm{L} \cdot \mathrm{h})$. The entrapping method of bacteria immobilization used in the study made a relatively higher microorganism concentration than the adsorption method used in our study. Moreover, the microorganism species harbored in the immobilization body also played an important role in nitrogen removal rate. For example, Qiao et al. [30] carried out co-immobilization of partial nitrifying and anammox biomass to achieve single-stage autotrophic nitrogen removal, and they found that the total nitrogen removal rate reached $70.42 \mathrm{mg} /(\mathrm{L} \cdot \mathrm{h})$ in a continuous experiment with nitrogen loading rate up to $91.67 \mathrm{mg} /(\mathrm{L} \cdot \mathrm{h})$.

\subsection{Biochar-based HNB Immobilization Body Performed Better to Remove $\mathrm{NH}_{4}{ }^{+}-\mathrm{N}$ than Biochar Itself}

After $5 \mathrm{~h}$ incubation, the removal ratio of $\mathrm{NH}_{4}{ }^{+}-\mathrm{N}$ by BC-based HNB immobilization bodies was significantly higher than BC itself. Under the condition of loading Pseudomonas sp. Strain-II, $\mathrm{NH}_{4}{ }^{+}-\mathrm{N}$ removal ratio ranged from $28.47 \%$ to $58.35 \%, 24.00 \%$ to $54.27 \%$, and $13.07 \%$ to $25.52 \%$ at the initial $\mathrm{NH}_{4}{ }^{+}-\mathrm{N}$ concentration of 100 , 200, and $300 \mathrm{mg} / \mathrm{L}$, respectively, with the order of $\mathrm{NaOH}+\mathrm{Mg}^{2+}$-modified $\mathrm{BC}>\mathrm{NaOH}$-modified $\mathrm{BC}>\mathrm{Mg}^{2+}$-modified 

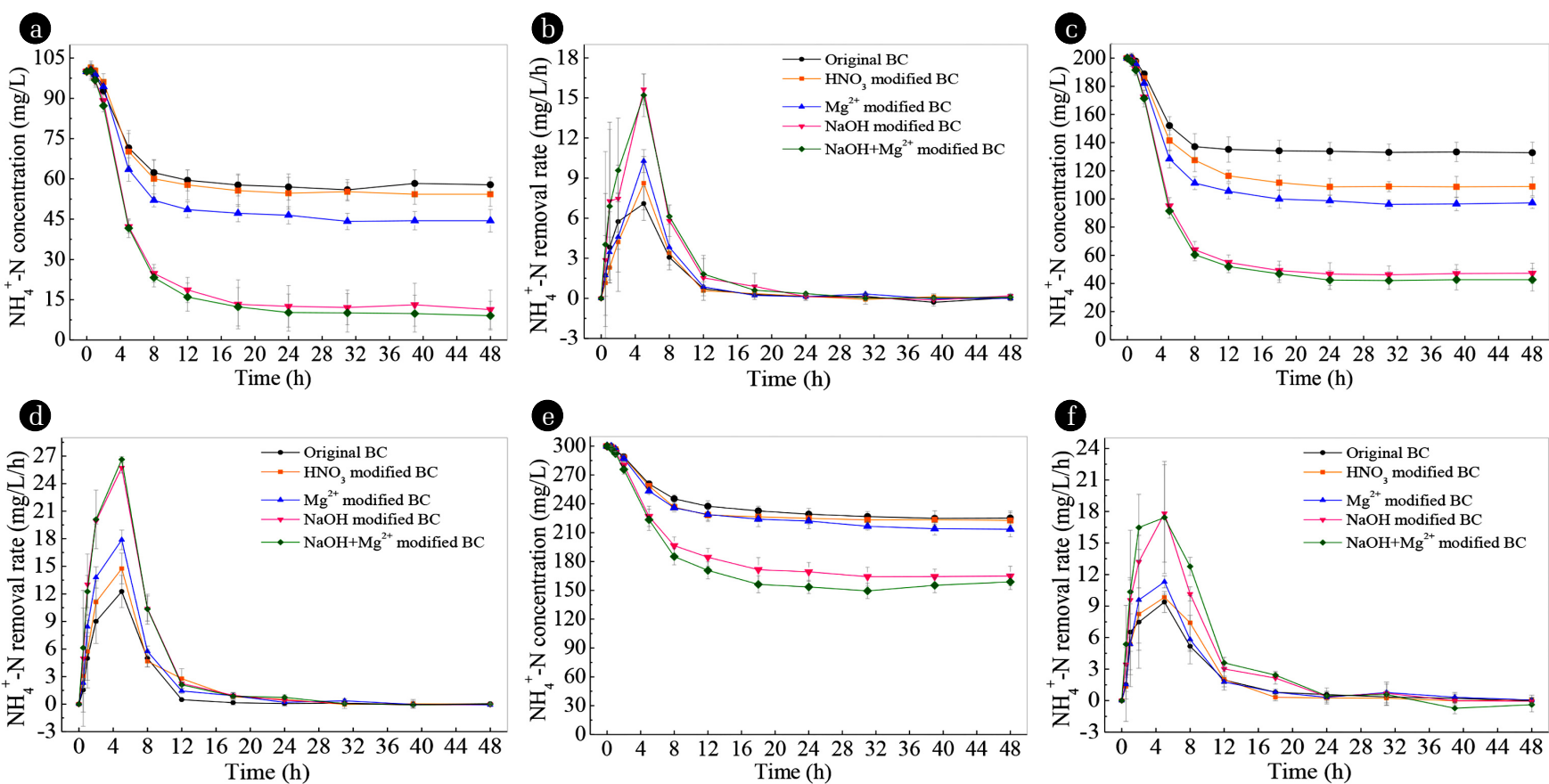

Fig. 3. $\mathrm{NH}_{4}{ }^{+}-\mathrm{N}$ removal dynamics of the original and modified biochar-based $\mathrm{HNB}$ immobilization bodies under the initial $\mathrm{NH}_{4}{ }^{+}-\mathrm{N}_{\text {concentration }}$ of $100(\mathrm{a}, \mathrm{b}), 200$ (c, d), and $300(\mathrm{e}, \mathrm{f}) \mathrm{mg} / \mathrm{L}$.

Table 2. Removal of $\mathrm{NH}_{4}{ }^{+}-\mathrm{N}$ by Biochar-immobilized Pseudomonas sp. Strain-II and Biochar without Loading Bacteria $\left(170 \mathrm{r} / \mathrm{min}, 30^{\circ} \mathrm{C}, 5 \mathrm{~h}\right.$ incubation)

\begin{tabular}{|c|c|c|c|c|c|c|c|}
\hline & & \multicolumn{2}{|c|}{$100 \mathrm{mg} / \mathrm{L}$} & \multicolumn{2}{|c|}{200 mg/L } & \multicolumn{2}{|c|}{$300 \mathrm{mg} / \mathrm{L}$} \\
\hline & & $\begin{array}{l}\text { Final concentration } \\
\qquad(\mathrm{mg} / \mathrm{L})\end{array}$ & $\begin{array}{c}\text { Removal ratio } \\
(\%)\end{array}$ & $\begin{array}{l}\text { Final concentration } \\
(\mathrm{mg} / \mathrm{L})\end{array}$ & $\begin{array}{c}\text { Removal ratio } \\
(\%)\end{array}$ & $\begin{array}{l}\text { Final concentration } \\
(\mathrm{mg} / \mathrm{L})\end{array}$ & $\begin{array}{c}\text { Removal ratio } \\
(\%)\end{array}$ \\
\hline \multirow{5}{*}{$\begin{array}{l}\text { Loading } \\
\text { Pseudomonas } \\
\text { sp. Strain-II }\end{array}$} & Original BC & $71.53 \pm 6.54$ & $28.47 \%$ & $151.99 \pm 6.36$ & $24.00 \%$ & $260.80 \pm 2.87$ & $13.07 \%$ \\
\hline & $\mathrm{HNO}_{3}$-modified $\mathrm{BC}$ & $70.19 \pm 6.66$ & $29.81 \%$ & $141.46 \pm 7.28$ & $29.27 \%$ & $258.70 \pm 4.65$ & $13.77 \%$ \\
\hline & $\mathrm{Mg}^{2+}$-modified BC & $63.49 \pm 4.39$ & $36.51 \%$ & $128.43 \pm 6.33$ & $35.79 \%$ & $253.33 \pm 2.99$ & $15.56 \%$ \\
\hline & $\mathrm{NaOH}$-modified BC & $42.22 \pm 2.39$ & $57.78 \%$ & $95.10 \pm 5.76$ & $52.45 \%$ & $226.90 \pm 10.64$ & $24.37 \%$ \\
\hline & $\mathrm{NaOH}+\mathrm{Mg}^{2+}$-modified $\mathrm{BC}$ & $41.65 \pm 3.51$ & $58.35 \%$ & $91.46 \pm 5.18$ & $54.27 \%$ & $223.45 \pm 11.10$ & $25.52 \%$ \\
\hline \multirow{5}{*}{$\begin{array}{l}\text { Unloading } \\
\text { Pseudomonas } \\
\text { sp. Strain-II }\end{array}$} & Original $\mathrm{BC}$ & $84.63 \pm 1.66$ & $15.37 \%$ & $171.44 \pm 1.39$ & $14.28 \%$ & $278.45 \pm 12.07$ & $7.18 \%$ \\
\hline & $\mathrm{HNO}_{3}$-modified $\mathrm{BC}$ & $92.67 \pm 0.17$ & $7.33 \%$ & $172.82 \pm 1.21$ & $13.59 \%$ & $278.83 \pm 5.21$ & $7.06 \%$ \\
\hline & $\mathrm{Mg}^{2+}$-modified BC & $95.26 \pm 6.03$ & $4.74 \%$ & $176.84 \pm 2.42$ & $11.58 \%$ & $286.88 \pm 8.93$ & $4.37 \%$ \\
\hline & NaOH-modified BC & $82.90 \pm 1.47$ & $17.10 \%$ & $157.87 \pm 6.85$ & $21.06 \%$ & $262.36 \pm 2.63$ & $12.55 \%$ \\
\hline & $\mathrm{NaOH}+\mathrm{Mg}^{2+}$-modified $\mathrm{BC}$ & $79.57 \pm 0.79$ & $20.43 \%$ & $145.80 \pm 1.21$ & $27.10 \%$ & $259.67 \pm 6.20$ & $13.44 \%$ \\
\hline
\end{tabular}

$\mathrm{BC}>\mathrm{HNO}_{3}$-modified $\mathrm{BC}>$ original $\mathrm{BC}$. However, under the condition of unloading Pseudomonas sp. Strain-II, $\mathrm{NH}_{4}{ }^{+}-\mathrm{N}$ removal ratio ranged from $4.74 \%$ to $20.43 \%, 11.58 \%$ to $27.10 \%$, and $4.37 \%$ to $13.44 \%$ at the initial $\mathrm{NH}_{4}{ }^{+}-\mathrm{N}$ concentration of 100,200 , and $300 \mathrm{mg} / \mathrm{L}$, respectively, with the order of $\mathrm{NaOH}+\mathrm{Mg}^{2+}$-modified $\mathrm{BC}>\mathrm{NaOH}$-modified $\mathrm{BC}>$ original $\mathrm{BC}>\mathrm{HNO}_{3}$-modified $\mathrm{BC}$ $>\mathrm{Mg}^{2+}$-modified BC (Table 2).

$\mathrm{NaOH}$ and $\mathrm{NaOH}+\mathrm{Mg}^{2+}$ modification enhanced $\mathrm{NH}_{4}{ }^{+}-\mathrm{N}$ adsorption ability of the rice husk-derived BC. At the initial $\mathrm{NH}_{4}{ }^{+}-\mathrm{N}$ concentration of $100 \mathrm{mg} / \mathrm{L}, \mathrm{NH}_{4}{ }^{+}-\mathrm{N}$ removal ratio shift from $15.37 \%$ (original BC) to $17.10 \%$ (NaOH-modified $\mathrm{BC}$ ) and $20.43 \%$ $\left(\mathrm{NaOH}+\mathrm{Mg}^{2+}\right.$-modified $\left.\mathrm{BC}\right)$ after $5 \mathrm{~h}$ incubation. Moreover, at the initial $\mathrm{NH}_{4}{ }^{+}-\mathrm{N}$ concentration of 200 and $300 \mathrm{mg} / \mathrm{L}, \mathrm{NH}_{4}{ }^{+}-\mathrm{N}$ removal ratio of $\mathrm{NaOH}$ and $\mathrm{NaOH}+\mathrm{Mg}^{2+}$ treatments was also higher than the original $\mathrm{BC}$ treatment with different extent (Table 2). Vu et al. [13] also concluded that the corncob BC modified by $\mathrm{HNO}_{3}+\mathrm{NaOH}$ had better $\mathrm{NH}_{4}{ }^{+}-\mathrm{N}$ adsorption capacity than the original and $\mathrm{HNO}_{3}$-modified BCs.

The rice husk-derived BC loaded with Pseudomonas sp. Strain-II, i.e. BC-based microbial immobilization body showed a much stronger ability to eliminate $\mathrm{NH}_{4}{ }^{+}-\mathrm{N}$ compared with $\mathrm{BC}$ itself. The result indicated that besides $\mathrm{NH}_{4}{ }^{+}-\mathrm{N}$ adsorption, $\mathrm{NH}_{4}{ }^{+}-\mathrm{N}$ microbial degradation played a much more prominent role in $\mathrm{NH}_{4}{ }^{+}-\mathrm{N}$ removal by BC-based microbial immobilization body in our study. Moreover, among all the five materials as the carrier of Pseudomonas sp. Strain-II, $\mathrm{NaOH}$ - and $\mathrm{NaOH}+\mathrm{Mg}^{2+}$-modified BC-based microbial 
immobilization bodies showed the strongest ability to remove $\mathrm{NH}_{4}{ }^{+} \mathrm{N}$. The main reason for this phenomenon may be that $\mathrm{NaOH}-$ and $\mathrm{NaOH}+\mathrm{Mg}^{2+}$-modified BC possessed significantly stronger bacteria adhering ability than original, $\mathrm{HNO}_{3}-$ or $\mathrm{Mg}^{2+}$-modified $\mathrm{BCs}$.

\subsection{Microbe Amount Adhering to the Surfaces of Original and Modified Biochars}

To explore the reason for the different $\mathrm{NH}_{4}{ }^{+}-\mathrm{N}$ removal performance of the original and modified BC-based HNB immobilization bodies, the number of living microbes adhering to the surface of the original and modified BCs were determined, which was indicated by the phospholipid content of cell membrane. After 24-h adsorption of Pseudomonas sp. Strain-II by BC, the BC-based immobilization body was isolated and its phospholipid content was determined. The result showed that all the four modification ways increased the bacteria adsorption ability, but with different extent. The phospholipid contents of the $\mathrm{NaOH}+\mathrm{Mg}^{2+}$ - and $\mathrm{NaOH}$-modified BC-based immobilization body (941.17 and $773.75 \mathrm{nmol} \mathrm{P/g} \mathrm{BC,}$ respectively) were significantly higher than the original BC-based immobilization body (608.12 $\mathrm{nmol} \mathrm{P/g} \mathrm{BC).} \mathrm{However,} \mathrm{there} \mathrm{was}$ no significant difference between $\mathrm{Mg}^{2+}$ - or $\mathrm{HNO}_{3}$-modified BC-based immobilization body (642.20 and $612.70 \mathrm{nmol} \mathrm{P} / \mathrm{g} \mathrm{BC}$ ) and the original $\mathrm{BC}(\mathrm{p}<0.05)$ (Fig. 4). The phenomenon indicated that $\mathrm{NaOH}+\mathrm{Mg}^{2+}$ and $\mathrm{NaOH}$ modification improved the ability of $\mathrm{BC}$ to adsorb microorganisms greatly, but not for $\mathrm{Mg}^{2+}$ or $\mathrm{HNO}_{3}$ modification methods.

Why $\mathrm{NaOH}$ - and $\mathrm{NaOH}+\mathrm{Mg}^{2+}$-modified biochar possessed prominent adsorption ability of $\mathrm{HNB}$ ? When bacteria adhered to the surface of $\mathrm{BC}$, the free bacteria and the $\mathrm{BC}$ hydrophobic surface attracts each other through van der Waals force, electrostatic force, etc., and then the viscous long-chain exopolysaccharide secreted by bacteria make the bacteria adhere to the surface of BC [31]. However, in our study, there are three main reasons making $\mathrm{NaOH}-$ and $\mathrm{NaOH}+\mathrm{Mg}^{2+}$-modified $\mathrm{BC}$ possess prominent adsorption ability of $\mathrm{HNB}$.

Firstly, bacteria adsorption capacity of BC relies on the large specific surface area and the pore structure of BC [12]. Generally, a large specific surface area and a rich pore structure could enhance the adsorption capacity of biochar, which may not only help bacteria

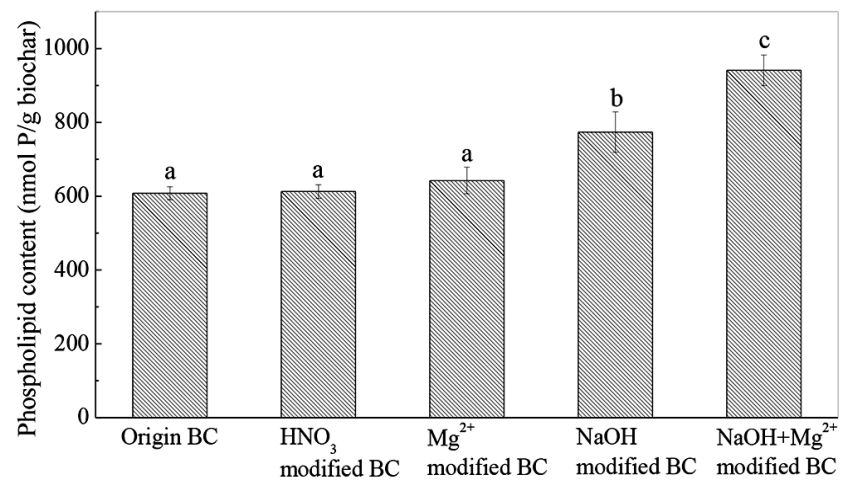

Fig. 4. Phospholipid content of Pseudomonas sp. Strain-II immobilized by the original and modified biochars (Bars following the same letter are not significantly different at $\mathrm{p}<0.05$ level of probability, $\mathrm{n}=3)$. adsorb to the surface of $\mathrm{BC}$, but also increase the chance of contact between bacteria and $\mathrm{NH}_{4}{ }^{+}-\mathrm{N}[12,32]$. Therefore, the $\mathrm{NaOH}$ - and $\mathrm{NaOH}+\mathrm{Mg}^{2+}$-modified BCs with the large specific surface area (2.99 and 3.56 times of original $\mathrm{BC}$ ) facilitated the adsorption of bacteria more readily than the original, $\mathrm{HNO}_{3}$ - and $\mathrm{Mg}^{2+}$-modified BCs. Secondly, $\mathrm{Mg}^{2+}$ loaded on the surface of BC could form a large number of metal derivatives with the functional groups of $\mathrm{BC}$ by ion exchange or complexation. $\mathrm{Mg}^{2+}$ derivatives formed on the surface of BC increased BC surface roughness and adsorption site, facilitating bacteria adhering [33, 34]. Thirdly, the electrostatic attraction between bacteria and $\mathrm{BC}$ is also a major reason why bacteria can adhere to the surface of BC [35]. Generally, the functional group on cell outer membrane of microbe has a net negative charge, which can be adsorbed by electrostatic attraction of the positively charged BC [36]. When preparing the BC-based microbial immobilization body, the original and modified BCs were immerged into the seed solution containing enriched HNB. However, the $\mathrm{pH}$ of the seed solution (near neutral) was lower than the $\mathrm{pH}_{\mathrm{pzc}}$ of $\mathrm{NaOH}-$ and $\mathrm{NaOH}+\mathrm{Mg}^{2+}$-modified $\mathrm{BCs}(8.87 \pm 0.57$ and 8.13 \pm 0.76 , respectively), making the surface of $\mathrm{NaOH}-$ and $\mathrm{NaOH}+\mathrm{Mg}^{2+}$-modified BCs be positively charged [24,37]. And then when $\mathrm{NaOH}$ - and $\mathrm{NaOH}+\mathrm{Mg}^{2+}$-modified BCs contacted the bacteria with negative charge, the electrostatic attraction between them makes bacteria adhere to the surface of $\mathrm{NaOH}-$ and $\mathrm{NaOH}+\mathrm{Mg}^{2+}$-modified BCs.

$\mathrm{NaOH}-$ and $\mathrm{NaOH}+\mathrm{Mg}^{2+}$-modified BC-based HNB immobilization bodies performed better than original, $\mathrm{HNO}_{3}$ - and $\mathrm{Mg}^{2+}$-modified BCs on $\mathrm{NH}_{4}{ }^{+}-\mathrm{N}$ removal from water. Besides the distinguished $\mathrm{NH}_{4}{ }^{+} \mathrm{N}$ adsorption ability and microbe adsorption capacity of $\mathrm{NaOH}-$ and $\mathrm{NaOH}+\mathrm{Mg}^{2+}$-modified $\mathrm{BCs}$, the significantly large amount of surface alkaline oxygen-containing functional group and the consequent high $\mathrm{pH}$ of them $(9.33 \pm 0.37$ and $10.20 \pm 0.30$, respectively) may also play an important role in promoting ammonia oxidation. $\mathrm{NH}_{3}$ is the substrate for ammonia-oxidizing microbes, and its concentration increases exponentially with increasing $\mathrm{pH}$ due to the deionization of $\mathrm{NH}_{4}{ }^{+}$to $\mathrm{NH}_{3}$ [38]. The considerable basic ions and groups in the region of biochar-water interface may facilitate the deionization process. On the other hand, nitrification could consume alkalinity, and generally high $\mathrm{pH}$ is conducive to nitrification [39]. Incidentally, oxygen is another important factor influencing nitrification. However, the air-permeable reaction apparatus and the constant rotation speed during incubation in our study could make no significant difference of oxygen concentration in the reaction system between treatments. In all, the alkaline property, large $\mathrm{HNB}$ adsorption capacity and $\mathrm{NH}_{4}{ }^{+}-\mathrm{N}$ adsorption ability of $\mathrm{NaOH}-$ and $\mathrm{NaOH}+\mathrm{Mg}^{2+}$-modified $\mathrm{BCs}$ render their immobilization bodies show excellent $\mathrm{NH}_{4}{ }^{+}-\mathrm{N}$ removal efficiency.

\section{Conclusions}

A strain of $\mathrm{HNB}$ was isolated, which was classified as Pseudomonas, and the 72-h $\mathrm{NH}_{4}{ }^{+}-\mathrm{N}$ removal ratio of the free bacteria reached $80.24 \% . \mathrm{NH}_{4}{ }^{+}-\mathrm{N}$ adsorption by the original and modified BC itself contributed little to $\mathrm{NH}_{4}{ }^{+}-\mathrm{N}$ removal from water solution. Compared with the BC without loading $\mathrm{HNB}$, the BC-based HNB immobilization body showed a much stronger ability to remove $\mathrm{NH}_{4}{ }^{+}-\mathrm{N}$, espe- 
cially for the $\mathrm{NaOH}-$ and $\mathrm{NaOH}+\mathrm{Mg}^{2+}$-modified BCs. At the initial $\mathrm{NH}_{4}{ }^{+}-\mathrm{N}$ concentration of $100 \mathrm{mg} / \mathrm{L}$ and biochar addition dose of $10 \mathrm{~g} / \mathrm{L}, \mathrm{NH}_{4}{ }^{+}-\mathrm{N}$ removal ratio of $\mathrm{NaOH}-$ and $\mathrm{NaOH}+\mathrm{Mg}^{2+}$-modified BC-based HNB immobilization bodies reached 57.78\% and 58.35\% after $5 \mathrm{~h}$, and reached $88.66 \%$ and $90.93 \%$ after $48 \mathrm{~h}$ respectively, which were obviously higher than the original, $\mathrm{HNO}_{3^{-}}$and $\mathrm{Mg}^{2+}$-modified BC-based HNB immobilization bodies. The phenomenon resulted from the significantly $(p<0.05)$ higher bacteria adsorption ability of $\mathrm{NaOH}$ - and $\mathrm{NaOH}+\mathrm{Mg}^{2+}$-modified $\mathrm{BCs}$, which reached 773.75 and $941.17 \mathrm{nmol} \mathrm{P} / \mathrm{g} \mathrm{BC}$, respectively.

\section{Acknowledgment}

This research was funded by the National Natural Science Foundation of China (No. 41503074) and the Natural Science Foundation of Shanxi Province (No. 201901D111066).

\section{Author Contributions}

C.W. (associate professor) conceived and designed the experiments. C.W. (associate professor) and J.R. (master student) performed the data analyses and wrote the manuscript. X.Q. (master student) conducted the experiments. M.H. (master student) helped review and edit the manuscript.

\section{References}

1. Jin $\mathrm{X}, \mathrm{Xu} \mathrm{Q}$, Huang C. Current status and future tendency of lake eutrophication in China. Sci. in China Ser. C: Life Sci. 2005;48:948-954.

2. Tanaka K, Sumino T, Nakamura H, Ogasawara T, Emori H. Application of nitrification by cells immobilized in polyethylene glycol. Progr. Biotech. 1996;11(96):622-632.

3. Kim JH, Rene ER, Park HS. Performance of an immobilized cell biofilter for ammonia removal from contaminated air stream. Chemosphere 2007;68:274-280.

4. Bai X, Ye ZF, Li YF, Zhou LC, Yang LQ. Preparation of crosslinked macroporous PVA foam carrier for immobilization of microorganisms. Process Biochem. 2010;45:60-66.

5. Dong Y, Zhang Z, Jin Y, Li Z, Lu J. Nitrification performance of nitrifying bacteria immobilized in waterborne polyurethane at low ammonia nitrogen concentrations. J. Environ. Sci. 2011;23:366-371.

6. Yu D, Liu W, Gao B, Yang M. The treatment of heterotrophic nitrification-aerobic denitrifying bacterial strains loaded by bacterial cellulose to domestic sewage: Treatment of immobilized bacteria to domestic sewage. In: 4th International Conference on Bioinformatics and Biomedical Engineering; 18-20 June 2010; p. 1-4.

7. Lehmann J, Joseph S. Biochar for environmental management: An introduction. In: Lehmann J, Joseph S, eds. Biochar for environmental management: Science and technology. London: Earthscan Publications Ltd.; 2009. p. 1-12.

8. Ahmad M, Rajapaksha AU, Lim JE, et al. Biochar as a sorbent for contaminant management in soil and water: A review. Chemosphere 2014;99:19-33.

9. Liu Y, Gan L, Chen Z, Megharaj M, Naidu R. Removal of nitrate using Paracoccus sp. YF1 immobilized on bamboo carbon. J. Hazard. Mater. 2012;229-230:419-425.

10. Xiong B, Zhang Y, Hou Y, Arp HPH, Reid BJ, Cai C. Enhanced biodegradation of PAHs in historically contaminated soil by M. gilvum inoculated biochar. Chemosphere 2017;182:316-324.

11. Zhang H, Tang J, Wang L, Liu J, Gurav RG, Sun K. A novel bioremediation strategy for petroleum hydrocarbon pollutants using salt tolerant Corynebacterium variabile HRJ4 and biochar. J. Environ. Sci. 2016;47:7-13.

12. Abu Talha M, Goswami M, Giri BS, Sharma A, Rai BN, Singh RS. Bioremediation of Congo red dye in immobilized batch and continuous packed bed bioreactor by Brevibacillus parabrevis using coconut shell biochar. Bioresour. Technol. 2018;252:37-43.

13. Vu TM, Trinh VT, Doan DP, et al. Removing ammonium from water using modified corncob-biochar. Sci. Total Environ. 2017;579:612-619.

14. Gong YP, Ni ZY, Xiong ZZ, Cheng LH, Xu XH. Phosphate and ammonium adsorption of the modified biochar based on Phragmites australis after phytoremediation. Environ. Sci. Pollut. Res. 2017;24:8326-8335.

15. Nguyen LH, Vu TM, Le TT, Trinh VT, Tran TP, Van HT. Ammonium removal from aqueous solutions by fixed-bed column using corncob-based modified biochar. Environ. Technol. 2019;40:683-692.

16. APHA, AWWA, WEF. Standard methods for the examination of water and wastewater. 22th ed. Washington, DC: American Public Health Association; 2012.

17. Edwards U, Rogall T, Blöcker H, Emde M, Böttger EC. Isolation and direct complete nucleotide determination of entire genes. Characterization of a gene coding for $16 \mathrm{~S}$ ribosomal RNA. Nucleic Acids Res. 1989;17:7843-7853.

18. Čerović LS, Milonjić SK, Todorović MB, et al. Point of zero charge of different carbides. Colloid. Surface. A 2007;297:1-6.

19. Boehm HP. Some aspects of the surface chemistry of carbon blacks and other carbons. Carbon 1994;32:759-769.

20. Wu LJ, Wang CX, Zhang F, Cui JG. The adsorption characters of inorganic nitrogen in aqueous solution by maize straw- and corn cob-derived biochars. China Environ. Sci. 2016;36:74-81. (in Chinese)

21. Wang JZ, Summers RS, Miltner RJ. Biofiltration performance: part 1, relationship to biomass. J. Am. Water Works Ass. 1995;87:55-63.

22. Yang L, Wang XH, Xiao Q, Ren YX, Chen N, Cui S. Kinetic characteristics and $\mathrm{N}_{2} \mathrm{O}$ production of a heterotrophic nitrifying bacterium Pseudomonas putida YH capable of tolerating adverse environmental conditions. J. Chem. Technol. Biotech. 2019;94(12): 3941-3950.

23. Carneiro Fidélis Silva L, Santiago Lima H, Antônio de Oliveira Mendes T, et al. Heterotrophic nitrifying/aerobic denitrifying bacteria: Ammonium removal under different physical-chemical conditions and molecular characterization. J. Environ. Manage. 2019;248:109294.

24. Zhou X, Zhou J, Liu Y, Guo J, Ren J, Zhou F. Preparation 
of iminodiacetic acid-modified magnetic biochar by carbonization, magnetization and functional modification for Cd(II) removal in water. Fuel 2018;233:469-479.

25. Shim JW, Park SJ, Ryu SK. Effect of modification with $\mathrm{HNO}_{3}$ and $\mathrm{NaOH}$ on metal adsorption by pitch-based activated carbon fibers. Carbon 2001;39:1635-1642.

26. Klinke HB, Thomsen AB, Ahring BK. Inhibition of ethanol-producing yeast and bacteria by degradation products produced during pre-treatment of biomass. Appl. Microbiol. Biot. 2004;66: 10-26.

27. Jin H, Hanif MU, Capareda S, Chang Z, Huang H, Ai Y. Copper(II) removal potential from aqueous solution by pyrolysis biochar derived from anaerobically digested algae-dairy-manure and effect of KOH activation. J. Environ. Chem. Eng. 2016;4:365-372.

28. Yu Y, An Q, Zhou Y, et al. Highly synergistic effects on ammonium removal by the co-system of Pseudomonas stutzeri XL-2 and modified walnut shell biochar. Bioresour. Technol. 2019;280:239-246.

29. Khan H, Bae W. Rapid start-up and efficient long-term nitritation of low strength ammonium wastewater with a sequencing batch reactor containing immobilized cells. Water Sci. Technol. 2014;70(3):517-523.

30. Qiao S, Tian T, Duan XM, Zhou JT, Cheng YJ. Novel single-stage autotrophic nitrogen removal via co-immobilizing partial nitrifying and anammox biomass. Chem. Eng. J. 2013;230:19-26.

31. Matin A, Khan Z, Zaidi SMJ, Boyce MC. Biofouling in reverse osmosis membranes for seawater desalination: Phenomena and prevention. Desalination 2011;281:1-16.
32. Xu X, Jin Z, Wang B, Lv C, Hu B, Shi D. Treatment of high-strength ammonium wastewater by polyvinyl alcohol-sodium alginate immobilization of activated sludge. Process Biochem. 2017;63: 214-220.

33. Jiang D, Chu B, Amano Y, Machida M. Removal and recovery of phosphate from water by Mg-laden biochar: Batch and column studies. Colloid. Surface. A 2018;558:429-437.

34. Xiao R, Wang JJ, Li R, et al. Enhanced sorption of hexavalent chromium [Cr(VI)] from aqueous solutions by diluted sulfuric acid-assisted MgO-coated biochar composite. Chemosphere 2018;208:408-416.

35. Xu X, Jin Z, Wang B, Lv C, Hu B, Shi D. Treatment of high-strength ammonium wastewater by polyvinyl alcohol-sodium alginate immobilization of activated sludge. Process Biochem. 2017;63: 214-220.

36. Yu Q, Boyanov MI, Liu J, Kemner KM, Fein JB. Adsorption of selenite onto Bacillus subtilis: The overlooked role of cell envelope sulfhydryl sites in the microbial conversion of Se(IV). Environ. Sci. Technol. 2018;52:10400-10407.

37. Li R, Liu L, Yang F. Preparation of polyaniline/reduced graphene oxide nanocomposite and its application in adsorption of aqueous Hg(II). Chem. Eng. J. 2013;229:460-468.

38. Kemmitt SJ, Wright D, Goulding KWT, Jones DL. pH regulation of carbon and nitrogen dynamics in two agricultural soils. Soil Biol. Biochem. 2006;38(5):898-911.

39. Sahrawat KL. Nitrification in some tropical soils. Plant Soil 1982;65(2):281-286. 